\title{
Households Carbon Emissions in Aceh, Indonesia: Regulator Perspective
}

\section{Widyana Verawaty SIREGAR ${ }^{1}$, Arnawan HASIBUAN ${ }^{2}$, KHAIRAWATI ${ }^{3}$, Doddy SETIAWAN ${ }^{4^{*}}$, Wahyu WIDARJO ${ }^{5}$}

\author{
${ }^{1}$ Faculty of Economics and Business, Universitas Malikussaleh, Indonesia \\ Email: widyana.verawaty@unimal.ac.id \\ ${ }^{2}$ Faculty of Engineering, Universitas Malikussaleh, Indonesia, Email: arnawan@unimal.ac.id \\ ${ }^{3}$ Faculty of Economics and Business, Universitas Malikussaleh, Indonesia, Email: khairawati@unimal.ac.id \\ ${ }^{4}$ Faculty of Economics and Business, Universitas Sebelas Maret, Indonesia \\ Email: doddy.setiawan@staff.uns.ac.id \\ ${ }^{5}$ Faculty of Economics and Business, Universitas Sebelas Maret, Indonesia \\ Email: widarjo@staff.uns.ac.id \\ ${ }^{*}$ Corresponding Author
}

\author{
Received: 29.04.2021 Accepted: 13.08.2021 Published: 20.10.2021 DOI: 10.47750/QAS/22.184.14
}

\begin{abstract}
Indonesia as one of the emerging markets have contribute to the carbon emission with the growth rate of $2.23 \% / y e a r s$. Indonesia. Indonesia needs to reduce the carbon emissions. One of important element to reduce or control carbon emissions is the role of government. The current study focus on the carbon emission from household in Aceh. Thus, current study using qualitative methods to investigate the role of government to reduce carbon emissions. The informant of the study are the important figures in the Local Environment Office in Banda Aceh. The result of the interview shows that the Local Environment Office as the regulator might not provide sufficient information to the people regarding the important of carbon emissions from the households. Mostly Local Environment Office focus on the carbon emission from the vehicle and industry. Therefore, Local Environment Office provide less attention on the carbon emissions from the households. Therefore, it is important for Local Environment Office to spend attention to the carbon emissions from the household. The current study suggest that the Office of Environment pay attention to carbon emissions from the households and provide relevant information to the public.
\end{abstract}

Keywords: households, carbon emissions, regulator, environment

\section{Introduction}

Various parties have paid much attention to global warming that triggers climate change, and they consider this issue a crucial problem and challenge. Increased carbon emission is a significant contributor to global warming. In turn, various factors contribute to increased carbon emission that triggers extreme temperature changes, including the energy sector. Increased income enhances life standards and public consumption that eventually increases energy consumption, especially electrical energy. From the sector-based approach, the housing sector is a sector that directly indicates public activities in terms of house energy usage. The household sector uses energy for lighting, cooking, air warming or cooling, and running vehicles for daily activities. Nowadays, an increasingly large number of home appliances use energy to operate that increase emission. Thus, the sectoral approach is less successful in illustrating the total influence of consumers' activities on energy use and the environmental impact of energy use. The data from the Indonesian Ministry of Environment demonstrates that the energy sectors contribute the most to greenhouse gas, especially $\mathrm{CO} 2$, as a consequence of households' use of electrical energy. Further, the data from the World Resource Institute indicates that Indonesia ranks sixth for emission gas contribution with the annual production of $\mathrm{CO} 2$ emission of 1.98 billion tons.
The energy consumption in Indonesia rises continuously along with increased economic activities in all user sectors, with the average annual growth of $2.53 \%$. The figure indicates that GDP growth is likely associated with emission growth. Thus, the public indirectly contributes to increased emission because increased energy demand is heavily affected by societal lifestyle. Consumptive society will need more energy. Conversely, a society that manages to control lifestyle will require less energy to produce goods and services.

Numerous studies, especially those in European countries, discuss the regulation and reduction of carbon emission. Efficient energy usage reduces carbon emission. Following the initiatives of the European Union, an increasing number of studies analyze the policy strategies of energy efficiency and the effectiveness of the existing policies (Murphy et al., 2012; Nilson, 2012; Rosenow \& Galvin, 2013; Rosenow et al., 2016). Numerous actions potentially prevent climate change, both at individual and governmental levels. Several studies have investigated the pattern of public support on governments' positive policies or actions (Aldy et al., 2012; Kotchen et al., 2013 Krosnick and MacInnis, 2013; Smith and Leiserowitz, 2014; Tvinnereim and Ivarsflaten, 2016; Tvinnereim dan Steinshamn, 2016).

This study illustrates how the government, as the regulator, evaluates public understanding of carbon emission and the impacts of their daily behavior, especially the household use of 
electrical energy, on carbon emission. This research also analyzes the role of the government's policies and regulations in preventing increased carbon emission as the regulator. Previous studies in several European countries demonstrate that the existing policies are based on public behavior and knowledge of energy usage to reduce carbon emission. However, these studies have not analyzed the electrical energy use of home appliances and the role of governments as regulators to raise public awareness on climate change and environmental concerns.

The reminder of the paper proceeds as follow: next section provides discussion on the regulator policies on carbon emission, section 3 provide research methods for the study, follow by the analysis and the last section present the conclusion.

\section{Policies On Carbon Emission Reduction And Public Contribution}

Climate change motivates Indonesia to participate in the United Nations Framework Convention on Climate Change and to issue Act No. 6 of 1994. Afterward, Indonesia actively supported the climate change controlling activities and routinely participated in climate change controlling activities such as Kyoto Protokol in 2004 and Bali Action Plan in 2007. Some results of these activities have been adopted as the departments and ministries' reference documents to identify emission reduction potentials and planned policies to reduce emission in Indonesia, such as the Second National Communication. (IESR report, 2011).

According to the IPCC report (2007), people contribute to greenhouse emission reduction by changing their lifestyles. In other words, empirical evidence moderately shows that changing lifestyles have a significant impact on gas emission changes. The arguments indirectly imply that people individually contribute to gas emission through energy demands due to their lifestyles. Consumptive society needs more energy. However, society that controls lifestyle will need less energy to produce goods and services.

According to the IESR report (2011), the development of settlement areas and different lifestyles likely increase emission.
From its composition, emission is dominated by the use of electrical appliances followed by lightings. The facts show that the use of electronic appliances contributes more to increased emission than the use of lightings. The results also demonstrate that people from all age intervals, occupations, and sexes exhibit similar patterns as the largest carbon emission producers through their electrical appliances. The report highlights the importance of verifying whether local areas are not familiar with the issue of efficient and low-carbon energy use.

According to the Brown to Green Report (BGR 2018), Indonesia is among countries that have not managed to comply with the Paris agreement (COP21). In this agreement, Indonesia pledged that its carbon emission would decrease by about 29 percent. In fact, carbon emission increased by 18 percent in Indonesia during the 2012-2017 period. The absence of longterm planning about emission in the energy sector and lack of strong willingness towards a low-carbon economic system are among the main causes of the failure to achieve the target. Thus, it takes appropriate policies and campaigns to inform the public about the importance of low carbon.

\section{Research Methods}

This study is an exploratory one by interviewing regulators in the energy and environment sectors. The interviews took between 30 and 50 minutes and used a semi-structured questionnaire that enabled participants to express their opinions and perspectives and analyzed the subjectivity of the experts' knowledge. Besides, the semi-structured questionnaire was designed to access and explore the knowledge and meaning according to the opinions of the head and staff of the department of environment. We then used the literature review in the discussion of the interviews.

The questions were divided into three themes. The first theme explored the knowledge of carbon emission and its determining factors. Next, the second theme explored the existing policies or regulations. Lastly, the third theme asked the obstacles. Table 1 displays the themes and outlines of the interview to analyze the extent of the government's role and socialization in raising public awareness to consume low emission.

\begin{tabular}{|c|c|}
\hline Theme & Outline \\
\hline $\begin{array}{l}\text { Carbon emission and its } \\
\text { determining factors }\end{array}$ & $\begin{array}{l}\text { - The determining factors of carbon } \\
\text { emission in daily lives } \\
\text { - The role of electrical appliances usage in } \\
\text { households }\end{array}$ \\
\hline Policies issued & $\begin{array}{l}\text { - } \quad \text { Main focus on reducing carbon emission } \\
\text { - } \quad \text { Policies implemented } \\
\text { - The results and evaluation of the existing } \\
\text { policies }\end{array}$ \\
\hline Obstacles & $\begin{array}{l}\text { - Obstacles in implementing policies } \\
\text { - Expectation }\end{array}$ \\
\hline
\end{tabular}

We recorded the interview results, transcripted, and coded by using the Nvivo as a software package to perform qualitative analysis. The study mainly based the data analysis process from the grounded theory (Strauss and Corbin, 1997) that was adopted in each dataset to develop a framework based on the collected data. The open-coding process produced codes in levels that were different from the theoretical complexity that would eventually regroup the codes into meta-code, and themes had been theoretically predetermined. The process continued until the theoretical maturation had been achieved and we analyzed inductively to illustrate the existing theme.

The grounded approach for data analysis (Strauss and
Corbin, 1997) was adopted for each dataset to develop the coding framework based on collected data and was not determined before the analysis. The following were the detailed phases: open-coding to produce codes at levels different from the theoretical complexity (from simple description to concept categories);

constant comparison between/ within codes to ensure that they 'fit' with the data; keeping the theoretical memos from emerging thoughts, perspectives, and concepts; and finally regrouping the codes into broader and theoretically more relevant meta-codes. The process continued until the theoretical maturation was achieved, and no new codes, themes, or 
perspectives produced.

\section{Result And Analysis}

Each of the following sections discusses the theme determined previously.

\section{a. Carbon Emission And Its Determinants}

In this theme, the interviews aimed to analyze the participants' opinions on carbon emission knowledge in general and the factors that cause carbon emission. In general, participants had sufficient knowledge of carbon emission and the factors that cause carbon emission. The interviews also revealed that the main focus of the department of environment was emission from both private and public transportation and industrial emission and not carbon emission from household electrical appliances.

"I have no clue about data on carbon emission from household electrical appliances."

"Gas stove and household generator are probably the most carbon emission contributors from household appliances. Thus, it's more related to household fuel consumption."

The interview results indicate that the government's policy to reduce carbon emission has not been optimal. In particular, we observed that the participants understood the factors that caused carbon emission and the impact of carbon emission on the environment. However, they only focused on industries and motor vehicles. The results are in line with Government Regulation (PP - Peraturan Pemerintah) No. 61 of 2011 concerning the restriction of vehicle circulation and fue (industrial) restriction. Thus, the policy to reduce carbon emission has not been optimal and only focused on motor vehicles and industrial fuel usage. Next, the environmental activists, especially those in the department of environment have not clearly understood the role of household electrical appliances in producing carbon emission. The results were in line with the observed government's inability to meet the Paris Agreement's targets (COP21) to reduce carbon emission.

The results suggest that the environmental activists need to acquire better knowledge and understanding to enable them to provide clearer comprehension to the public about the daily factors that cause carbon emission and to illustrate the impacts of increased carbon emission due to daily lifestyles. Thus, comprehensive training and technical assistance will potentially enhance the knowledge of carbon emission and the understanding of the government's policies to achieve the carbon emission reduction target. Overall, the study advises professionals to gain a better understanding of the characteristics of carbon emission from household electrical appliances and the impacts of using these appliances wisely and correctly.

\section{b. Policies Implemented}

For this theme, the interview aimed to understand policies implemented concerning carbon emission in general and the results of those policies. The participants have implemented policies concerning carbon emission reduction for motor vehicles, industrial fuel usage, and garbage combustion in the settlement areas.

"Although hierarchically the municipal environment offices (cities or regencies) are not the subordinates of the provincial environment office, there is still a coordination line between them through technical assistance. The technical assistances facilitate the communication of aspirations and policies."

"We installed emission measurement devices in several points, including in the settlement areas to measure carbon emission in the areas and to evaluate the results."

"Numerous municipals have implemented green open space policies to reduce carbon emission in densely populated areas or areas with high emission."

"We initiated cooperation with the local city planning office on air quality. Besides, the regional and city planning offices have directly socialized about air quality and its impacts on health and the environment."

The results illustrate that although emission detection devices have been installed in several points, including in settlement areas, the government still considered that emission was only because of motor vehicles and garbage combustion and not affected by electrical appliances. Further, the policies have followed a policy in Government Regulation No. 61 of 2011 concerning the development of green open space. The evaluation of the detection tools also indicates that the policies only focused on smoke and combustion due to fuel and motor vehicle and completely overlooked household electrical appliances. Thus, the section suggests policymakers and professionals issue policies that give a better understanding of the impact of electrical appliances on emission and household energy-saving activities.

\section{c. Obstacles}

In this theme, the interview examined obstacles in implementing the policies concerning carbon emission and expectations from these policies.

"I think it is not a cliche that fund is the main obstacle in the implementation. For example, lack of funds hinders us from socializing in numerous local societies that reside in such vast areas."

"Besides fund, public lack of understanding and ignorance of the environmental impacts of carbon emission are also the obstacles. People only care about their daily needs."

The interviews suggest that fund was the crucial factor in implementing all education activities and implementing the policies to the public. However, the environment professionals still had expectations and planned policies to participate in carbon emission reduction.

"It is an obstacle but also an expectation of continuing educating the public about carbon emission and its impacts on them."

"Besides socializing about the importance of maintaining motor vehicles, using public transport, and using energy especially fuel - efficiently to reduce carbon emission, it is also important to socialize about the efficient use of electrical appliances and the impacts of using electrical energy excessively on health and environment."

"We continue the socialization to local societies with heads of villages as the spearheads. We will also likely cooperate with religious leaders to make it easier to win people's hearts and minds."

\section{Conclusions}

The study underscores the knowledge of carbon emission and its impacts on the environment, policies to be implemented, and expectations on carbon emission reduction in Indonesia that focuses on household electrical appliances. We interviewed the heads and staff at the environment unit at the local environment and forestry office as the regulator of carbon emission policies.

The study asked a series of questions about the factors that caused carbon emission and related them with the information that has been or will be communicated to the public and the form of communication. During the interviews, several key questions were asked. i.e., questions that asked about the knowledge of 
carbon emission from household electrical appliances. The participants speculatively argue that lack of knowledge on the impacts of household electrical appliances as the cause of carbon emission. Consequently, as the information source, the regulator needs to gain a better understanding of the impacts of increased carbon emission from household electrical appliances. Besides, they have to participate more in training and to learn regulations and rules concerning the government's policies to reduce carbon emission.

Next, the government should aim for sustainability and increased knowledge of and support for the government's programs. Information that is needed by consumers must be linked with their daily lives to help them understand better the information. Also, trustworthy sources should transfer the information to the society. To conclude, better knowledge of the carbon emission impacts of household electrical appliances will inform the society better. Further, policies to raise environmental awareness will have significant effects on consumers' green and pro-environment behavior in saving electricity use.

The current study focuses on the qualitative study of the regulator perceive on the carbon emission reduction. Therefore, it is suggested the further study investigate how stakeholders such as society and business perceive the carbon emissions.

\section{References}

[1] Aldy, J.E. (2012). Promoting clean energy in the American power sector: A proposal for a national clean energy standard. Environ. Law Rep. 42, 10131-10149

[2] Brown to Green Report. (2018) (www.climate-transparency.org)

[3] Charnaz K. (2006) Constructing Grounded Theory : a Practical Guide Through Qualitative Analysis (Intro do city Qualitative Method Series), Sage, Thousand Oaks, CA.

[4] Glaser, B., Strauss, A. (1967). The Discovery of Grounded Theory, Weidenfield and Nicolson, London

[5] Henwood, K. L., \& Pidgeon, N. F. (1992). Qualitative research and psychological theorizing. British Journal of Psychology, 83(1), 97-111. doi: 10.1111/j.2044-8295.1992.tb02426.x

[6] IPCC. (2007). IPCC Fourth Assessment Report Climate Change
2007 , Pachauri, R.K and Reisinger, A (eds). Published: Geneva, Swiss.

[7] Institute for Essential Service Reform (IESR). (2011) www.iesr.or.id

[8] Kotchen, M. J., Boyle, K. J., \& Leiserowitz, A. A. (2013) Willingness-to-pay and policy-instrument choice for climatechange policy in the United States. Energy Policy, 55, 617-625. doi: 10.1016/j.enpol.2012.12.058

[9] Krosnick, J. A., \& MacInnis, B. (2013). Does the American Public Support Legislation to Reduce Greenhouse Gas Emissions? Daedalus, 142(1), 26-39. doi: 10.1162/daed_a_00183

[10] Murphy, L., Meijer, F., \& Visscher, H. (2012). A qualitative evaluation of policy instruments used to improve energy performance of existing private dwellings in the Netherlands. Energy Policy, 45, 459-468. doi: 10.1016/j.enpol.2012.02.056

[11] Nilsson, M. (2012). Energy governance in the European Union: Enabling conditions for a low carbon transition? In G. Verbong, D. Lorbach (eds.) Governing the energy transition: Reality, illusion, or necessity? New York: Routledge, p. 296-316.

[12] Rosenow, J., \& Galvin, R. (2013). Evaluating the evaluations: Evidence from energy efficiency programmes in Germany and the UK. Energy and Buildings, 62, 450-458. doi: 10.1016/j.enbuild.2013.03.021

[13] Rosenow, J., Fawcett, T., Eyre, N., \& Oikonomou, V. (2016). Energy efficiency and the policy mix. Building Research \& Information, 44(5-6), 562-574. doi: 10.1080/09613218.2016.1138803

[14] Strauss, A., Corbin, J.M. (1997). Grounded Theory in Practise, Sage, London

[15] Smith, N., \& Leiserowitz, A. (2013). The Role of Emotion in Global Warming Policy Support and Opposition. Risk Analysis, 34(5), 937-948. doi: 10.1111/risa.12140

[16] Tvinnereim, E., \& Fløttum, K. (2015). Explaining topic prevalence in answers to open-ended survey questions about climate change. Nature Climate Change, 5(8), 744-747. doi: 10.1038/nclimate2663

[17] Tvinnereim, E., \& Ivarsflaten, E. (2016). Fossil fuels, employment, and support for climate policies. Energy Policy, 96, 364-371. doi: 10.1016/j.enpol.2016.05.052

[18] World Resources Institut Indonesia (www. Wri-indonesia.org) 